\title{
DRONE BRINGS NEW ADVANCE OF GEOLOGICAL MAPPING IN MONGOLIA: OPPORTUNITIES AND CHALLENGES
}

\author{
Otgonbayar Dandar*, Atsushi Okamoto, Masaoki Uno, Undarmaa Batsaikhan, \\ Burenjargal Ulziiburen, Noriyoshi Tsuchiya
}

Graduate School of Environmental Studies, Tohoku University, Japan

*Corresponding author. Email: Otogo@geokankyo.tohoku.ac.jp

\section{ARTICLE INFO}

Article history:

Received 1 September 2018

Accepted 26 December 2018

\begin{abstract}
Unmanned aerial vehicles (UAVs) or drones have revolutionized scientific research in multiple fields. Drones provide us multiple advantages over conventional geological mapping or high-altitude remote sensing methods, in which they allow us to acquire data more rapidly of inaccessible or risky outcrops, and can connect the spatial scale gap in mapping between manual field techniques and airborne, highaltitude remote sensing methods. Despite the decreased cost and technological developments of platforms, sensors and software, the use of drones for geological mapping in Mongolia has not yet been utilized. In this study, we present using of drone in two areas: the Chandman area in which eclogite is exposed and the Naran massif of the Khantaishir ophiolite in the Altai area. Drone yields images with high resolution that is reliable to use and reveals that it is possible to make better formulation of geological mapping. Our suggestion is that (1) Mongolian geoscientists are encouraged to add drones to their geologic toolboxes and (2) drone could open new advance of geological mapping in Mongolia in which geological map will be created in more effective and more detailed way combined with conventional geological survey on ground.
\end{abstract}

Keywords: remote sensing, inaccessible outcrops, geological map

\section{INTRODUCTION}

In the last decade, unmanned aerial vehicles (UAVs) or drones have become widely available for use in a broad range of disciplines (Watts et al., 2012). Drones are reforming scientific research in multiple fields including detailed geological mapping (Piras et al., 2017), environmental science (e.g. Mlambo et al., 2017), forestry (e.g. Sankey et al., 2017), geological education (Jordan, 2015), geothermal research (e.g. Nishar et al., 2016), hydrology (Bandini et al., 2017), natural hazards (e.g. Mateos et al., 2017), structural geology (e.g. Bemis et al., 2014) and etc. Geological mapping is a complex and time-consuming activity, especially when performing in mountain area (e.g., Joyce et al., 2014). Expert geologists can accomplish ground mapping but they do not

(C) The Author(s). 2018 Open access This article is distributed under the terms of the Creative Commons Attribution 4.0 International License (https://creativecommons.org/licenses/by/4.0/), which permits unrestricted use, distribution, and reproduction in any medium, provided you give appropriate credit to the original author(s) and source, provide a link to the Creative Commons license, and indicate if changes were made. 


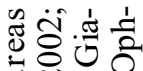

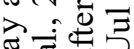
त त
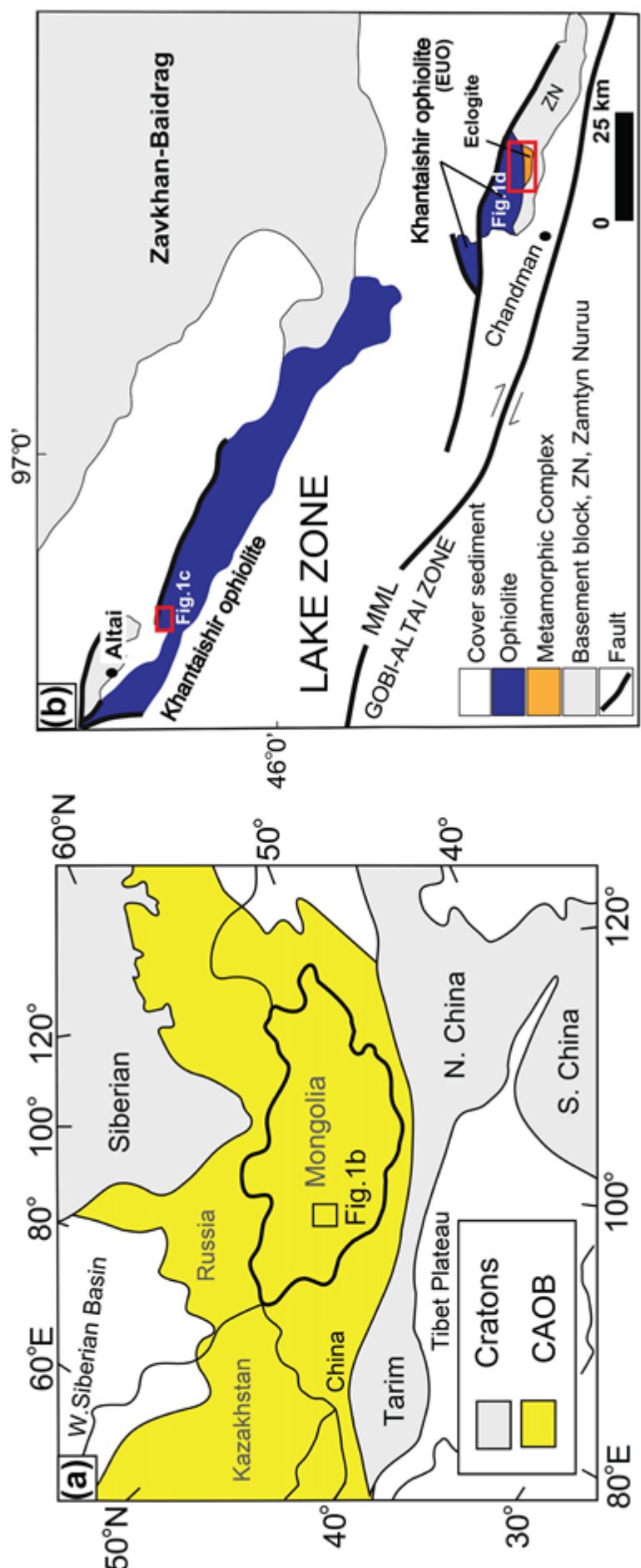
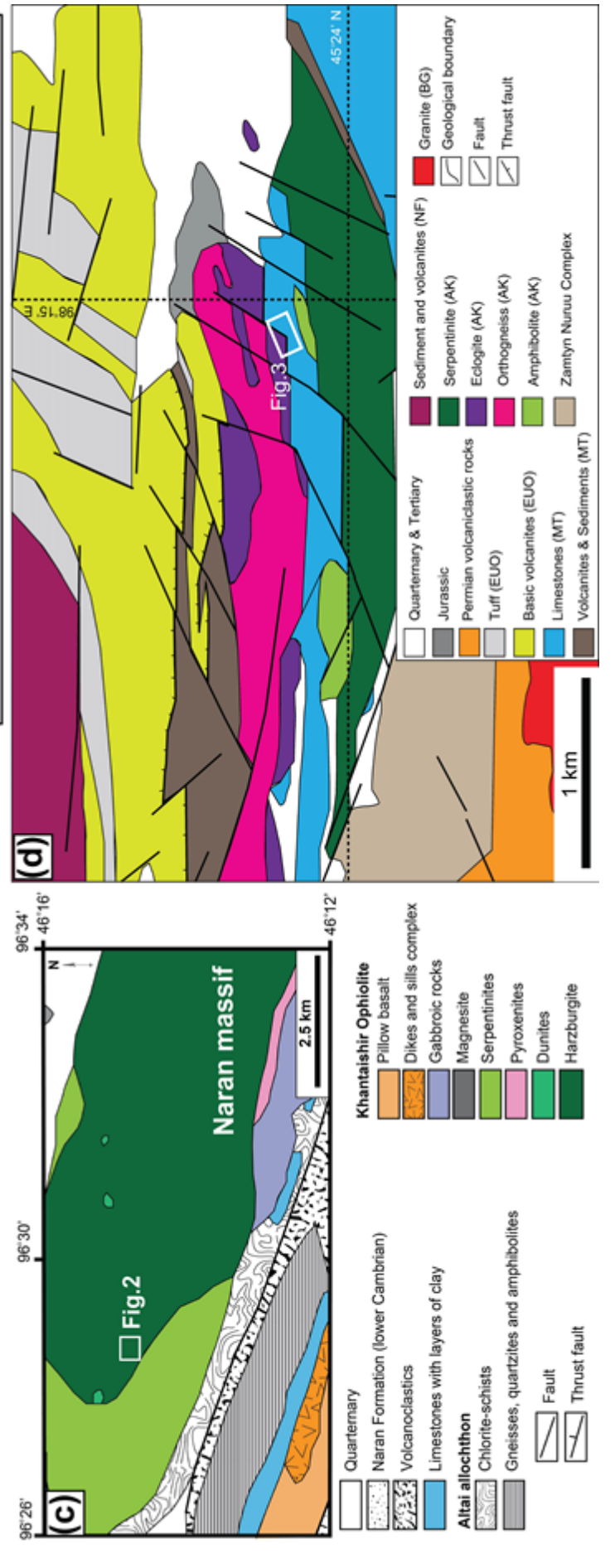

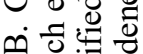

을

ஸ

式导四

\& च

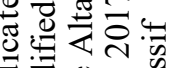

ఏ气

๘ $\Xi \pm \frac{0}{0}$

สั.

공.을 을 볼

बहीं की

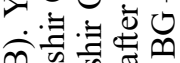

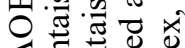

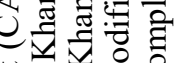

워워

บ

政西

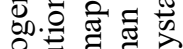

○ํㅡㅇ

ป.

.

运.

중요예 च유:巳一 บ흐응

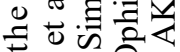
फ记

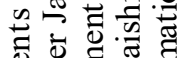

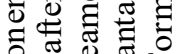

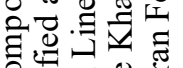

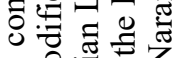
ธ。

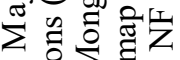
เ

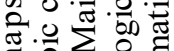
츙ㅇㅇㅇ ชู

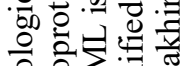
융

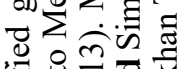

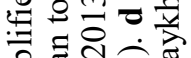
的兽完令 -云完 는 䲶 元

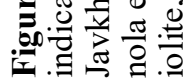


always attain a whole overview of the area. Currently, many cartographic geological products are obtained by coupling satellite images and field surveys. However, drone can acquire data more rapidly and less expensively than typical airborne surveys and can produce good data for geological mapping combined with ground mapping (Piras et al., 2017). Although drones can play an important and innovative role in numerous applications, the use of drones has not yet been utilized in Mongolian geological mapping.

In this contribution, we present using of drone in two areas: the Chandman area where the eclogite is exposed and the Naran massif of the Khantaishir ophiolite in the Altai area. Results of drone show images with high resolution that can be used for geological mapping. We then discuss opportunities and challenges of using drone in Mongolia.

\section{GEOLOGICAL SETTING}

The Khantaishir ophiolite is located in the Lake zone (Badarch et al., 2002). The ophiolite is interpreted as exposed in two areas: in the Altai area and in the Chandman area (Zonenshein and Kuzmin 1978). In the Altai area, the unbroken ophiolite sequence is exposed and ultramafic rocks are divided into two massifs: the Taishir and the Naran (Matsumoto and Tumortogoo, 2003). In the Chandman area, the ophiolite is cropped out as volcanic rocks and small ultramafic body close to eclogite bodies (Stipska et al., 2010; Javklan et al., 2013).

\section{METHODOLOGY}

Fieldwork was conducted in the Chandman area and the Altai area. In the Chandman area boundary between the eclogite and limestone was selected whereas in the Altai area, ultramafic rock's outcrop (the Naran massif) of the Khantaishir ophiolite was chosen to capture overlapping aerial photographs. Detailed outcrop observation of selected geobodies was also carried out on the ground. In this study, we used an Inspire 1 (drone) quadcopter with $4 \mathrm{k}$ camera and 3 axis Gimbal. Before take off, calibrations were made to ensure the platform was orientated prior to take-off. We carried out more than 3 flight missions for each area, capturing a total of 361 pictures, and half day of drone field work with a capacity of six drone batteries. The captured pictures were combined using photoscan commercial program and height of flight was varied ca. $100 \mathrm{~m}$ from ground surface.

\section{RESULTS}

Two drone images were taken from two areas (Fig.1 c and d). In the Altai area, one part of ultramafic body (the Naran massif: $0.07 \mathrm{~km}^{2}$ area) was investigated (Fig.1c). Figure 2 shows comparison between Google Earth Imagery and drone image. Google Earth Imagery shows low resolution and has shadow (Fig.2a). Drone yields image with high resolution and we can see outcrop of ultramafic rocks in summit of mountain (Fig.2b). In the Chandman area (0.08 $\mathrm{km}^{2}$ area), boundary between the eclogite and limestone was investigated (Fig.1d).

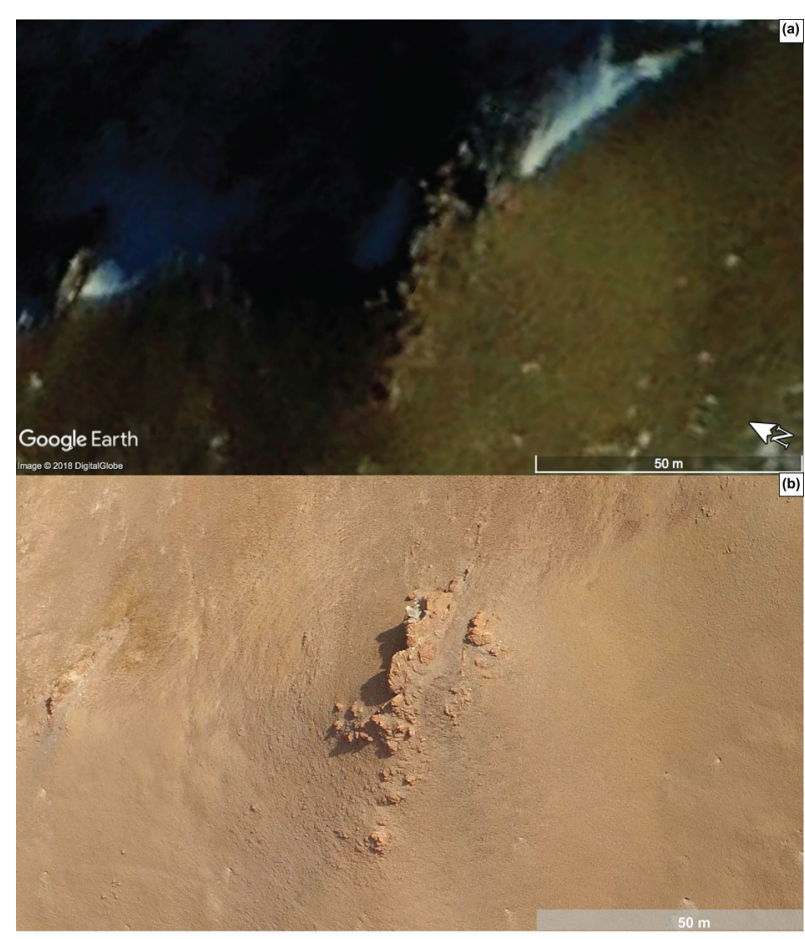

Figure 2. Comparison between Google Earth Imagery and drone image. a Google Earth Imagery shows low resolution and is affected by sun's angle. b drone image in the Altai area. The outcrops are clearly shown.

Figure 3 shows comparison between Google Earth Imagery and drone image. Google Earth Imagery shows also low resolution whereas 
drone image has high resolution and outcrop of rocks is distinguishable.

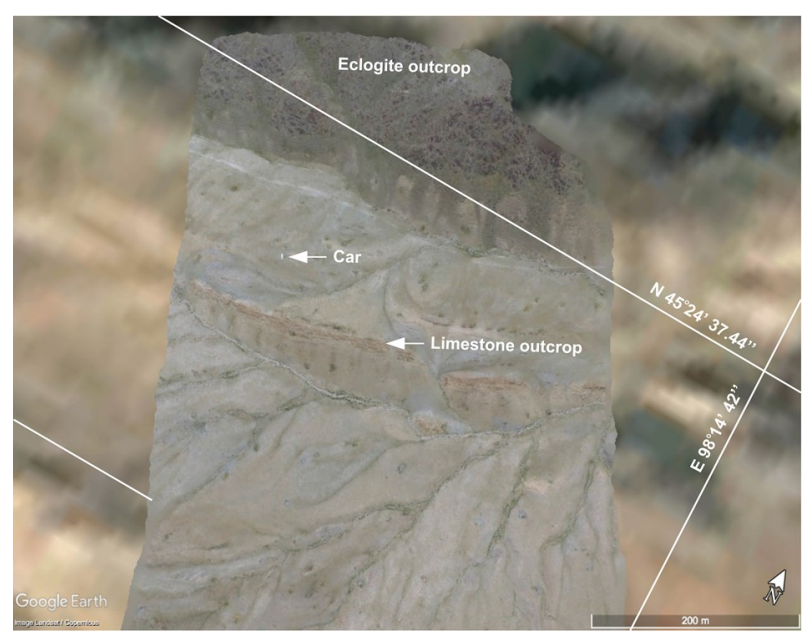

Figure 3. Comparison between Google Earth Imagery and drone image. Google Earth Imagery shows very low resolution whereas drone image shows very high resolution. Outcrops are clearly distinguishable

\section{Challenges}

\section{DISCUSSION}

The challenges in using drone in Mongolia can be divided into three categories as following: Natural; Technological; and Legal.

In the natural case, the biggest challenge of using drone is weather dependent. Mongolia has strong winds in mountain range (average is 7.1$8.1 \mathrm{~m} / \mathrm{s}$ at $30 \mathrm{~m}$; Elliott et al., 2001). High winds $(>8 \mathrm{~m} / \mathrm{s})$ can severely limit control or flight time, due to loss of battery power as the drone tries to maintain its position. Drones are not waterproof, which limits their use in rainy conditions (Jordan, 2015).

In term of technological case, drone flight times are limited by their power source. Another issue is the scale of view from the drone image.

Finally, use of drone should have law regulated by government. Although civil aviation rule 101 regulates use of drone in Mongolia (Civil Aviation authority of Mongolia), most users of drone do not know about the law in detail. It is important that users, researchers and educators should know the law. Educators use drone to do so responsibly and train students in the ethics of their use.

\section{Opportunities}

Our resent results show images with high resolution that can be used directly in geological mapping. In case of Mongolian Geological mapping, 1:50000 scale of geological mapping has covered only $34 \%$ of Mongolian territory (Mineral Resources and Petroleum Authority of Mongolia). Therefore, drone can be used in geological mapping for rest of Mongolian territory because geological map can be generated more rapidly and less expensive by drone combined with ground mapping (Piras et al., 2016). In addition, drone can be used in education for students (Jordan, 2015). Based on previous and present work, drone can bring excellent advantage for geological mapping in Mongolia.

\section{REFERENCES}

Badarch, G., Dickson-Cunningham, W., and Windley, BF., 2002, A new terrane subdivision for Mongolia: Implications for the Phanerozoic crustal growth of Central Asia: Journal of Asian Earth Sciences, v. 21, p. 87-110.

Bandini, F., Jakobsen, J., Olesen, D., ReynaGutierrez, J.A., and Bauer-Gottwein, P., 2017, Measuring water level in rivers and lakes from lightweight Unmanned Aerial Vehicles: Journal of Hydrology, v. 548, p. 237-250.

Bemis, S.P., Micklethwaite, S., Turner, D., James, M.R., Akciz, S., Thiele, S.T., and Bangash, H.A., 2014, Ground-based and UAV-Based photogrammetry: a multi-scale, high-re- solution mapping tool for structural geology and paleoseismology: Journal of Structural Geology, v. 69, p. 163-178.

Buriánek , D., Shulmann, K., Hrdličková, K., Hanžl, P., Janoušek, V., Gerdes, A., and Lexa, O., 2017. Geochemical and geochronological constraints on distinct Early-Neoproterozoic and Cambrian accretionary events along southern margin of the Baydrag Continent in western Mongolia: Godwana Research, v. 91, p. 181-193.

Civil Aviation authority of Mongolia (2015, October). Wings, v. 63, Retrieved from http:// www.mcaa.gov.mn/wp-content/ uploads/2016/05/63-wings-2015.pdf. 
Elliott , D., Sschwartz, M., Scott, G., Haymes, S., Heimiller, D., and George, R., 2001. Wind energy resource atlas of Mongolia, NREL/TP -500-26129, National Renewable Energy Lab, Golden, Colo., August.

Gianola, O., Schidt, M.W., Jagoutz, O., and Sambuu, O., 2017. Incipient boninitic arc crust built on denudated mantle: the Khantaishir ophiolite (western Mongolia): Contributions to Mineralogy and Petrology, v. 172:92, https://doi.org/10.1007/s00410017-1415-4.

Jahn, B.M., Wu, F.Y., and Chen, B., 2000. Granitoids of the Central Asian Orogenic Belt and continental growth in the Phanerozoic. Transactions of the Royal Society of Edinburgh: Earth Sciences, v. 91, p. 181-193.

Javkhlan, O., Takasu, A., Bat-Ulzii, D., and Kabir, F., 2013, Metamorphic pressuretemperature evolution of garnet-chloritoid schists from the Lake Zone, SW Mongolia: Journal of Mineralogical and Petrological Sciences, v.108, p. 255-266.

Jordan B.R., 2015, A bird's-eye view of geology: The use of micro drones/UAVs in geologic fieldwork and education: Geological Society of America today, v. 25, doi: 10.1130/GSATG232GW.1.

Joyce, KE., Samsonov, SV., Levick, SR., Engelbrecht, J., and Belliss, S., 2014, Mapping and monitoring geological hazards using optical, LiDAR, and synthetic aperture RADAR image data: Nat Hazards: v. 73, p. 137-163.

Mateos, R.M., Azanon, J.M., Roldan, F.J., Notti, D., Perez-Pena, V., Galve, J.P., Perez-Garcia, J.L., Colomo, C.M., Gomez-Lopez, J.M., Montserrat, O., Devantery, N., LamasFernandez, and F., Fernandez-Chacon, F., 2017, The combined use of PSInSAR and UAV photogrammetry techniques for the analysis of the kinematics of a coastal landslide affecting an urban area (SE Spain): Landslides, v. 14, p. 743-754.

Matsumoto, I., and Tomurtogoo, O., 2003, Petrological characteristics of the Hantaishir Ophiolite Complex, Altai Region, Mongolia: Coexistence of podiform chromitite and boninite: Gondvana Research, v. 6, p. 161169

Mlambo, R., Woodhouse, I.H., Gerard, F., and Anderson, K., 2017, Structure from motion (SfM) photogrammetry with drone data: a low cost method for monitoring green- house gas emissions from forests in developing countries: Forests, v. 8, doi:10.3390/ f8030068.

Mineral Resources and Petroleum Authority of Mongolia. 2016. Retrieved from https:// www.mrpam.gov.mn/article/47/

Nishar, A., Richards, S., Breen, D., Robertson, J., and Breen, B., 2016, Thermal infrared imaging of geothermal environments and by an unmanned aerial vehicle (UAV): a case study of the Wairakei - tauhara geothermal field, Taupo, New Zealand: Renew. Energy, v. 86, p. $1256-1264$.

Piras, M., Taddia, G., Forno, M. G., Gattiglio, M., Aicardi. I., Dabove, P., Russo, S. Lo., and Lingua, A., 2017, Detailed geological mapping in mountain areas using an unmanned aerial vehicle: application to the Rodoretto Valley, NW Italian Alps: Geomatics, Natural Hazards and Risk, v. 8:1, p. 137-149.

Sankey, T., Donager, J., McVay, J., Sankey, J.B., 2017, UAV lidar and hyperspectral fusion for forest monitoring in the southwestern USA: Remote Sensing of Environment, v. 195, p. 30-43.

Štípská, P., Schulmann, K., Lehmann, J., Corsini, M., Lexa, O., and Tomurhuu, D., 2010, Early Cambrian eclogites in SW Mongolia: Evidence that the Palaeo-Asian Ocean suture extends further east than expected: Journal of Metamorphic Geology, v. 28, p. 915-933.

Watts, A.C., Ambrosia, V.G., and Hinkley, E.A., 2012, Unmanned aircraft systems in remote sensing and scientific research: classification and considerations of use: Remote Sensing, v. 4, p. 1671-1692.

Zonenshain, L.P., and Kuzmin, M.I., 1978, The Khan-Taishir ophiolitic complex of western Mongolia, its petrology, origin and comparison with other ophiolitic complexes: Contributions to Mineralogy and Petrology, v. 67, p. 95-109. 